\title{
Rapid assay to assess colonization patterns following in-vivo probiotic ingestion
}

\author{
Jacinta M Tobin', Suzanne M Garland ${ }^{2,3,4}$, Susan E Jacobs ${ }^{3,4,5}$, Marie Pirotta ${ }^{6}$ and Sepehr N Tabrizi ${ }^{2,3,4^{*}}$
}

\begin{abstract}
Background: Colonization of the intestine with some microorganisms has been shown to have beneficial health effects. The association of bacteria with its human host starts soon after birth; however in infants born prematurely establishment of normal intestinal flora is interrupted with colonization with potential pathogenic organisms Probiotic supplementation may therefore be beneficial to the health of preterm infants. As most probiotic organisms are difficult to culture, confirmation of their colonization after supplementation is difficult. In this study, rapid qPCR assays for detection of presence of probiotic species in the intestine by faecal sampling is described in both preterm infant and adult participants.
\end{abstract}

Findings: Probiotic colonization was determined using QPCR directed at amplification of organisms present in the ingested probiotic Streptococcus thermophilus, Bifidobacterium animalis subsp. lactis and B. longum subsp. infantis. Overall, differential detection of probiotic strains in faeces were found between adult and preterm infants, with 50\% of infants continuing to shed at least two probiotic strains three weeks after probiotic ingestion had ceased.

Conclusions: This study demonstrated rapid assessment of the preterm infant gut for colonization with probiotic strains using real-time PCR. This method would be of great importance in studies of probiotics in prevention of diseases and adverse clinical outcomes.

Keywords: Probiotics, qPCR, Preterm infant, Micro biome

\section{Findings}

The intestinal micro biota contains a diverse range of bacterial species [1]. The bacterial community has also been shown to have a symbiotic relationship with their human host and is beneficial to human health $[2,3]$. This association starts soon after birth [4]. Bifidobacterium species (B. spp), commonly found in the intestine of healthy infants, may influence postnatal immune development, including susceptibility to sepsis and allergic diseases [5]. In preterm infants, the development of the intestinal micro biome is affected by the neonatal intensive care unit environment, with decreased microbial diversity, including colonization with potential pathogens and association with late-onset sepsis and necrotizing enterocolitis [6,7]. Supplementation with appropriate

\footnotetext{
* Correspondence: Sepehr.tabrizi@thewomens.org.au

2Department of Microbiology and Infectious Diseases, The Royal Women's

Hospital, Parkville, VIC, Australia

${ }^{3}$ Department of Obstetrics and Gynaecology, University of Melbourne,

Parkville, VIC 3052, Australia

Full list of author information is available at the end of the article
}

probiotic strains including B.spp may therefore be beneficial to the health of preterm infants, subject to confirmation of detection in fecal output and possible colonization. However, probiotic organisms are mostly fastidious anaerobes and difficult to culture using conventional techniques, as well as difficult to speciate, being closely related to other naturally occurring species [8]. Rapid, sensitive, molecular tests can provide a faster and more accurate method to confirm micro biota colonization $[9,10]$. In this study, changes in detection of in-vivo probiotic ingested organisms were measured using quantitative real-time PCR directed to specific detection of the three organisms present in the formulation.

Following approval by the Royal Women's Hospital Human Research and Ethics Committees, 12 preterm infants born below 32 weeks gestation, weighing less than $1500 \mathrm{~g}$ and seven healthy adult volunteers were recruited to participate. Written informed consent for participation in the study was obtained from participants or, in cases of infants from their parent or guardian. The probiotic 
Table 1 PCR primer and probes sequences utilized in the study

\begin{tabular}{|c|c|c|}
\hline \multirow[b]{2}{*}{ Target } & \multicolumn{2}{|l|}{ Sequence $\left(5^{\prime}-3^{\prime}\right)^{a}$} \\
\hline & Primer/probe & Ref \\
\hline \multirow[t]{3}{*}{ B. animalis subsp. lactis } & F: GTGGAGACACGGTTTCCC & [13] \\
\hline & R: CACACCACACAATCCAATAC & [13] \\
\hline & P: FAM-TTCACAGGTGGTGCATGGTCGT BHQ1 & This paper \\
\hline \multirow[t]{3}{*}{ B. longum subsp. infantis } & F: TTCCAGTTGATCGCATGGTC & [12] \\
\hline & R: GGAAACCCCATCTCTGGGAT & [12] \\
\hline & P: CY5-TCAAgCCCAggTAAggTTCTTCgC BHQ3 & This paper \\
\hline \multirow[t]{3}{*}{ S. thermophilus } & F: TTATTTGAAAGGGGCAATTGCT & [11] Modified \\
\hline & R: GTGAACTTTCCACTCTCACAC & [11] Modified \\
\hline & P: CY5-ACTACAAGATGGACCTGCGT BHQ3 & This paper \\
\hline
\end{tabular}

${ }^{a}$ Nucleotide bases among the primers and probes that are underlined represent locked nucleic acid bases. $F$, forward primer; $R$, reverse primer; $P$, probe; FAM, 6-carboxyfluorescein; Cy5, cyanine 5; BHQ, Black Hole Quencher.

formulation, $A B C$ Dophilus for Infants $^{\circledR}$, (Solgar, New York, USA) containing $2 \times 10^{8}$ Bifidobacterium longum subsp. infantis, $2.3 \times 10^{8} \mathrm{~B}$. animalis subsp. lactis and $2.3 \times 10^{8}$ Streptococcus thermophilus per gram was ingested by adult participants ( $15 \mathrm{~g}$ or $10^{10}$ organisms) and 6 preterm infants (1.5 g or $10^{9}$ organisms) for seven days, while six control infants were fed routinely with their mother's expressed breast milk.

Specimens for assay were collected by rotating a flocked swab in feces, and then rotated in $400 \mu \mathrm{L}$ of phosphate buffered saline (PBS). Fecal samples were collected prior to and at completion of probiotic ingestion, then weekly up to 4 weeks and stored at $-80^{\circ} \mathrm{C}$ until analyzed. Two hundred $\mu$ l of cell suspensions were extracted using MagNA Pure LC system (Roche Diagnostics, Branchburg, NJ) with the associated DNA Isolation Kit I protocol. DNA was eluted in a final volume of $100 \mu \mathrm{L}$ of MagNA Pure Elution Buffer (Roche Diagnostics). Extracted DNA was tested by three quantitative real-time PCR (qPCR) assays for detection of B. longum subsp. infantis, S. thermophilus and B. lactis. These assays are not strain specific and will only detect the respective species within the sample being tested.

Each qPCRs was performed using the Light Cycler 480 real-time instrument (Roche Diagnostics), with each reaction comprised of a $20 \mu \mathrm{l}$ volume, containing $1 \mathrm{x}$ Light Cycler 480 probes master mix (Roche Diagnostics), $1.0 \mu \mathrm{M}$ each previously published specie-specific primers [11-13] (Table 1), $200 \mathrm{nM}$ each probe (Table 1), and $5 \mu \mathrm{l}$ of DNA template. All qPCR reactions had the same cycling parameters of $95^{\circ} \mathrm{C}$ for 10 minutes followed by $50 \mathrm{cy}$ cles of $95^{\circ} \mathrm{C}$ for 10 seconds and $60^{\circ} \mathrm{C}$ for 55 seconds. Data for each sample were plotted as a derivative of fluorescence versus temperature. All samples which yielded linear increases in their fluorescence readings relative to the negative control sample were considered positive. Strict procedures avoiding specimen contamination and carryover were followed.

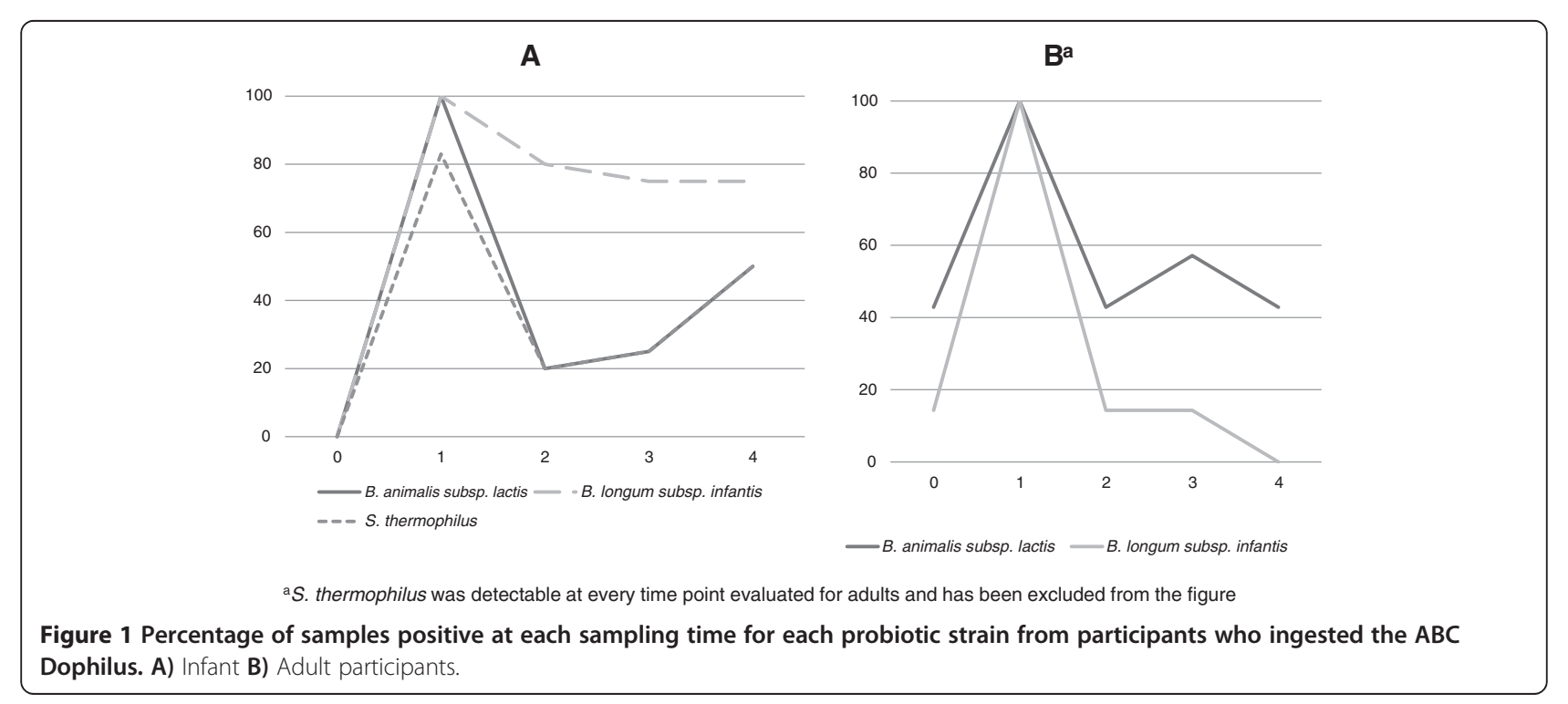


All three probiotic species were detectable in 83\% (5/6) of infants who ingested probiotics by Week 1 (Figure 1A). None of the three probiotic species were detected in the 12 preterm infants' feces at Week 0 and subsequently none of the 6 control infants had the probiotic strains detected. B. longum subsp. infantis continued to be detected in $75 \%$ of the infants four weeks after probiotic ingestion had ceased.

In the adult group, S. thermophilus was present before and throughout the intervention in all participants, due to presence of this organism in readily available cheese and yoghurts. B. longum subsp. infantis was detected in feces of all 7 adult participants at Week 1, but not four weeks after probiotic ingestion had ceased, whereas B. animalis subsp. lactis was detectable in up to $40 \%$ of adults, 4 weeks post probiotic ingestion (Figure 1B).

It is important to test a pre-supplementation sample to ensure the subject is not positive for the probiotic organisms prior to its administration, as it is possible for gut micro biota to already contain the organism [14]. This study demonstrated rapid assessment using realtime PCR of preterm infant gut for colonization of ingested probiotic strains. This method would be a valuable tool in studies evaluating probiotics in prevention of diseases and adverse clinical outcomes [15].

\section{Competing interests}

In the past 5 years none of the authors have received reimbursements, fees, funding or salary from any organization that may in any way gain or lose financially from the publication of this manuscript either now or in the future. In addition there is no non-financial competing interest to declare in relation to this manuscript.

\section{Authors' contributions}

ST, SG, JT, MP and SJ conceived and participated in the design of the study. ST carried out qPCR as well as drafted the manuscript. SG, JT, SJ, MP assisted in preparation of the manuscript. JT and SG coordinated the specimen collection. All authors read and approved the final manuscript.

\section{Author details}

'Northwest Academic Centre University of Melbourne, Sunshine Hospital, St Albans, VIC 3021, Australia. ${ }^{2}$ Department of Microbiology and Infectious Diseases, The Royal Women's Hospital, Parkville, VIC, Australia. ${ }^{3}$ Department of Obstetrics and Gynaecology, University of Melbourne, Parkville, VIC 3052, Australia. ${ }^{4}$ Murdoch Childrens Research Institute, Parkville, VIC 3052, Australia. ${ }^{5}$ Neonatal Services, The Royal Women's Hospital, Parkville, VIC, Australia.

${ }^{6}$ Department of General Practice, University of Melbourne, Parkville, VIC 3052, Australia.

Received: 6 November 2012 Accepted: 3 July 2013

Published: 5 July 2013

\section{References}

1. Eckburg PB, Bik EM, Bernstein CN, Purdom E, Dethlefsen L, Sargent M, Gill SR, Nelson KE, Relman DA: Diversity of the human intestinal microbial flora. Science 2005, 308(5728):1635-1638.

2. Hooper LV, Bry L, Falk PG, Gordon Jl: Host-microbial symbiosis in the mammalian intestine: exploring an internal ecosystem. Bioessays 1998, 20(4):336-343.

3. Mazmanian SK, Liu CH, Tzianabos AO, Kasper DL: An immunomodulatory molecule of symbiotic bacteria directs maturation of the host immune system. Cell 2005, 122(1):107-118.
4. Huurre A, Kalliomaki M, Rautava S, Rinne M, Salminen S, Isolauri E: Mode of delivery - effects on gut micro biota and humoral immunity. Neonatology 2008, 93(4):236-240

5. Prescott SL, Bjorksten B: Probiotics for the prevention or treatment of allergic diseases. J Allergy Clin Immunol 2007, 120(2):255-262.

6. Penders J, Thijs C, Vink C, Stelma FF, Snijders B, Kummeling I, van den Brandt PA, Stobberingh EE: Factors influencing the composition of the intestinal micro biota in early infancy. Pediatrics 2006, 118(2):511-521.

7. Schwiertz A, Gruhl B, Lobnitz M, Michel P, Radke M, Blaut M: Development of the intestinal bacterial composition in hospitalized preterm infants in comparison with breast-fed, full-term infants. Pediatr Res 2003, 54(3):393-399

8. Léké $\mathrm{A}$, Romond MB, Mullié C: Insights in the Human Bifidobacterial Flora Through Culture-Dependent and Independent Techniques. In Communicating Current Research and Educational Topics and Trends in Applied Microbiology, Volume 2. Edited by Méndez-Vilas A. Badajoz, Spain: Formatex: 2007:758-765.

9. Pammi M, Flores A, Leeflang M, Versalovic J: Molecular assays in the diagnosis of neonatal sepsis: a systematic review and meta-analysis. Pediatrics 2011, 128(4):e973-e985.

10. Venkatesh M, Flores A, Luna RA, Versalovic J: Molecular microbiological methods in the diagnosis of neonatal sepsis. Expert Rev Anti Infect Ther 2010, 8(9):1037-1048.

11. Furet JP, Quenee P, Tailliez P: Molecular quantification of lactic acid bacteria in fermented milk products using real-time quantitative PCR. Int J Food Microbiol 2004, 97(2):197-207.

12. Matsuki T, Watanabe K, Tanaka R, Fukuda M, Oyaizu H: Distribution of bifidobacterial species in human intestinal microflora examined with $16 \mathrm{~S}$ rRNA-gene-targeted species-specific primers. Appl Environ Microbiol 1999, 65(10):4506-4512

13. Ventura $M$, Reniero R, Zink R: Specific identification and targeted characterization of Bifidobacterium lactis from different environmental isolates by a combined multiplex-PCR approach. Appl Environ Microbiol 2001, 67(6):2760-2765

14. Turroni F, Peano C, Pass DA, Foroni E, Severgnini M, Claesson MJ, Kerr C, Hourihane J, Murray D, Fuligni F, et al: Diversity of bifidobacteria within the infant guts micro biota. PLoS One 2012, 7(5):e36957.

15. Garland S, Tobin J, Pirotta M, Tabrizi S, Opie G, Donath S, Tang M, Morley C, Hickey $L$, Ung $L$, et al: The ProPrems trial: investigating the effects of probiotics on late onset sepsis in very preterm infants. BMC Infect Dis 2011, 11(1):210

doi:10.1186/1756-0500-6-252

Cite this article as: Tobin et al:: Rapid assay to assess colonization patterns following in-vivo probiotic ingestion. BMC Research Notes 2013 6:252.

\section{Submit your next manuscript to BioMed Central and take full advantage of:}

- Convenient online submission

- Thorough peer review

- No space constraints or color figure charges

- Immediate publication on acceptance

- Inclusion in PubMed, CAS, Scopus and Google Scholar

- Research which is freely available for redistribution 